Time to Go 
This page intentionally left blank 


\title{
Time to Go
}

Three Plays on Death and Dying with Commentary on End-of-Life Issues

\author{
Edited by \\ Anne Hunsaker Hawkins, Ph.D. and \\ James O. Ballard, M.D. \\ with \\ Theodore Blaisdell, M.D.
}

University of Pennsylvania Press

Philadelphia 
The University of Pennsylvania Press will grant permission for performance of the plays in Time to Go only on the condition that performances will be free of charge. Parties requesting that this condition be waived must secure written permission from the author of the play in question, who can be contacted c/o the University of Pennsylvania Press.

Copyright $\odot$ I 995 by the Doctors Kienle Center for Humanistic Medicine All rights reserved

Library of Congress Cataloging-in-Publication Data

Time to go: three plays on death and dying, with commentary on end-of-life issues / edited by Anne Hunsaker Hawkins and James O. Ballard with Theodore Blaisdell.

p. $\mathrm{cm}$.

Includes bibliographical references and index.

Contents: Journey into that good night / Berry L. Barta-Stars at the break of day / Marjorie Ellen Spence-Time to go / CE McClelland.

ISBN 0-8I 22-I 5I9-2

I. Death-Drama. 2. Do-not-resuscitate orders - Drama. 3. American drama-20th century. 4. Right to die-Drama. I. Hawkins, Anne Hunsaker, I944- . II. Ballard, James O. III. Blaisdell, Theodore.

PS627.D42T56 1995

$306.9-\mathrm{dc} 20$ 


$$
\begin{aligned}
& \text { Dedicated to the memory of } \\
& \text { JANE WITMER KIENLE, M.D. }
\end{aligned}
$$


This page intentionally left blank 